\title{
Analisis Pemilihan Dukun sebagai Penolong Persalinan (Studi Kasus di Puskesmas Bulak Banteng, Kota Surabaya)
}

\author{
Nurul Habibah Umar* \\ *Program Studi Pengembangan Sumber Daya Manusia, Sekolah Pascasarjana Universitas Airlangga \\ Surabaya \\ Email : bibapsdmua2017@gmail.com
}

\section{ABSTRACT}

Maternal mortality of Surabaya, in 2017, reached 79.40 per 100,000 live births due to direct causes by $77.2 \%$. There are many programs to reduce maternal mortality and infant mortality such as improving delivery services in the health facility. In 2008, the partnership program between midwives and traditional birth attendants had developed to increase the access of quality maternal services for mothers and babies. However, in 2017 the delivery practice with traditional birth attendants has remained active in the area of Bulak Banteng Community Health Center, Surabaya.

This study aimed to analyze the women's decision selecting the traditional birth attendants for their delivery practice by exploring knowledge factor, belief factor, health service access factor, and family factor in Bulak Banteng Community Health Center of Surabaya. The research was a qualitative study using the approach of case study including in-depth interview and exploring secondary data. The sample was the mothers who delivered the baby with the traditional birth attendant from a previous year ago, and the midwife of health community center. The variable from this study were knowledge factor, belief factor, health service access factor, and family factor. The study used the analytical method consisted of data collecting, data reduction, and verification.

The result showed less knowledge factor of healthy and safe delivery in the community. The belief factor and family factor held an important role in the selection of the traditional birth attendants during birth attendance, while the factor of health service access showed nothing related to the selection process. There is a need to implement health education for pregnant women, husband, family, and people with an aim of giving the understanding about healthy and safe birth attendance. In conclude, the selection on traditional birth attendant was influenced by knowledge factor, belief factor, and family factor.

Keywords: Birth Attendant; Delivery Pactice; Traditional Birth Attendant

\section{PENDAHULUAN}

Angka Kematian Ibu (AKI) dan angka kematian bayi (AKB) merupakan salah satu indikator penting derajat kesehatan suatu bangsa. AKI dan AKB di Indonesia masih tinggi apabila dibandingkan dengan negara - negara di ASEAN lainnya. Menurut Survei Penduduk Antar Sensus (SUPAS) tahun 2015, AKI di Indonesia yaitu 305/100.000 
kelahiran hidup. Hal ini sama seperti AKB AKB di Indonesia tahun 2015 yaitu 23 per 1.000 kelahiran hidup. Di Kota Surabaya, AKI pada tahun 2017 yaitu 79,40 per 100.000 Kelahiran Hidup ${ }^{1}$.

Pada tahun 2011, Badan Penelitian dan Pengembangan Kesehatan (Litbangkes), Kementerian Kesehatan (Kemenkes) RI bekerja sama dengan Badan Pusat Statistik (BPS) melakukan studi tindak lanjut penyebab kematian ibu berbasis sensus penduduk tahun 2010. Hasil studi tersebut yaitu 77,2\% kematian ibu disebabkan karena penyebab langsung ${ }^{2}$.

Berbagai upaya dilakukan dalam rangka penurunan AKI dan AKB. Salah satu upaya prioritas dalam penurunan AKI dan AKB tahun 2015 - 2019 yaitu peningkatan pelayanan persalinan di fasilitas kesehatan. Peningkatan pelayanan pertolongan persalinan dengan menerapkan standart asuhan persalinan normal, termasuk penggunaan partograf, dan pemberian injeksi oksitosin kepada ibu segera setelah bayi lahir.

Dinas Kesehatan Kota Surabaya merupakan salah satu organisasi perangkat daerah yang bertanggung jawab atas pembangunan kesehatan di Kota Surabaya termasuk dalam pelaksanaan upaya prioritas diatas. Di Kota Surabaya terdapat 2 Rumah Sakit Umum Daerah milik pemerintah kota Surabaya dan 63 Puskesmas yang tersebar di 31 Kecamatan. Dengan persebaran jumlah Puskesmas di seluruh Kecamatan diharapkan dapat mendukung upaya peningkatan pelayanan persalinan di fasilitas kesehatan.

Pada tahun 2008, dikembangkan program kemitraan bidan dan dukun untuk meningkatkan akses ibu dan bayi terhadap pelayanan kebidanan yang berkualitas. Suatu program bentuk kerjasama bidan dengan dukun yang saling menguntungkan dengan prinsip keterbukaan, kesetaraan, dan kepercayaan dalam upaya untuk menyelamatkan ibu dan bayi, dengan menempatkan bidan sebagai penolong persalinan dan mengalih-fungsikan dukun dari penolong persalinan menjadi mitra dalam merawat ibu dan bayi pada masa nifas, dengan berdasarkan kesepakatan yang telah dibuat antara bidan dengan dukun, serta melibatkan seluruh unsur/ elemen masyarakat yang ada $^{3}$. Dukun bayi adalah seorang wanita atau pria yang menolong persalinan. Kemampuan ini diperoleh secara turun menurun dari ibu kepada anak atau dari keluarga dekat lainnya. Cara mendapatkan keterampilan ini adalah melalui magang dari pengalaman sendiri atau saat membantu melahirkan ${ }^{4}$. Peranan dukun bayi tidak hanya sebatas pada pertolongan persalinan saja tetapi juga meliputi berbagai segi lainnya, seperti mencucikan baju setelah ibu melahirkan, memandikan bayi selama tali pusar belum puput (lepas), memijit ibu setelah melahirkan, memandikan ibu, mencuci rambut ibu setelah 40 hari melahirkan ${ }^{5}$.

Berdasarkan keahliannya, jenis dukun bermacam - macam yaitu: 1) dukun pijat yang bekerja untuk menyembuhkan penyakit yang disebabkan karena kurang berfungsinya urat - urat dan aliran darah (salah urat), sehingga orang yang merasa kurang sehat ataupun sakitpun perlu diurut supaya sembuh, 2) dukun sangkal putung/ dukun patah tulang misalnya akibat jatuh dari pohon, tergelincir atau kecelakaan, 3) dukun petungan, yaitu dukun yang dimintai nasehat tentang waktu yang sebaiknya dipiilih untuk melakukan sesuatu usaha yang penting seperti saat mulai menanam padi, mulai panen, atau mengawinkan anak. Nasehat yang diberikan berupa perhitungan hari mana 
yang baik, dan mana yang tidak baik menurut numerologi Jawa, 4) dukun dukun yang pandai mengobati orang orang yang digigit ular berbisa, 5) dukun bayi yaitu mereka yang memberi pertolongan persalinan ${ }^{6}$.

Melalui kemitraan bidan dukun, peran dukun sebagai kader kesehatan ibu dan bayi baru lahir dapat ditingkatkan? Keberhasilan kemitraan bidan dukun ini juga didukung oleh sistem monitoring dan evaluasi dari Pemerintah dan lintas sektor ${ }^{8}$.

Pada tahun 2017 di Kota Surabaya masih ditemukan 24 orang ibu bersalin yang ditolong oleh tenaga non kesehatan yaitu dukun. Jumlah dukun yang ada di Surabaya pada tahun 2017 yaitu 29 orang dengan distribusi terbanyak yaitu di wilayah Puskesmas Bulak Banteng dan Perak Timur. Apabila dibandingkan dari kedua Puskesmas tersebut, di wilayah kerja Puskesmas Bulak Banteng yang masih ditemukan pertolongan persalinan oleh dukun.

Tak dapat disangkal lagi, ilmu kedokteran modern telah berkembang pesat sehingga meninggalkan konsep lama yang dibatasi oleh penggunaan teknis medis modern dalam melawan penyakit. Upaya bidang kesehatan masyarakat seperti peningkatan taraf kesehatan perseorangan, pendidikan kesehatan, pencegahan dan pemberantasan penyakit menular, dan keluarga berencana harus juga memperhitungkan pengetahuan pengetahuan lain mengenai kebiasaan, adat istiadat, dan tingkat pengetahuan traditional medicine masyarakat setempat ${ }^{9}$. Penelitian ini merupakan contoh pendekatan antropologi medis ${ }^{10}$. Mengapa masyarakat masih sulit berobat ke fasilitas pelayanan kesehatan. Walaupun untuk masalah kesehatan ini, misalnya penggunaan alat kontrasepsi, telah ada perubahan $^{11}$.

Dari latar belakang diatas, perlu dilakukan analisis pemilihan dukun sebagai penolong persalinan di Puskesmas Bulak Banteng, Surabaya.

\section{METODE PENELITIAN}

Penelitian ini adalah penelitian kualitatif dengan metode studi kasus. Pengumpulan data melalui wawancara menggunakan pedoman wawancara mendalam dan data sekunder yang ada di Puskesmas. Penelitian dilaksanakan di Puskesmas Bulak Banteng Kota Surabaya. Informan utama dalam penelitian ini adalah ibu yang pernah bersalin di dukun pada 1 tahun yang lalu sebanyak 3 orang, dengan informan pendamping adalah bidan Puskesmas sebanyak 2 orang. Data primer yang diambil melalui wawancara dan data sekunder melalui telaah dokumen. Variabel yang diteliti yaitu faktor pengetahuan, faktor kepercayaan, faktor akses pelayanan kesehatan dan faktor keluarga. Metode analisis yang digunakan yaitu pengumpulan data, reduksi data dan verifikasi.

\section{HASIL DAN PEMBAHASAN \\ Faktor Pengetahuan}

Pengetahuan merupakan salah satu ranah perilaku selain sikap dan tindakan atau praktik $^{12}$. Dari hasil wawancara didapatkan hampir semua informan memiliki pengetahuan yang cukup tentang persalinan. Pengetahuan tentang persalinan tersebut bukan merupakan pengertian persalinan yang sehat dan aman. Seperti kutipan hasil wawancara berikut:

\footnotetext{
"Ngelairno iku yo bayekE karo ari - arine lahir" “(Melahirkan itu adalah bayi dan plasentanya lahir)“ (In A 1)

"Nek nang bidan, laer bayine trus dijahit. Aku gak
} 
wani dijahit"

"(Kalau di Bidan, lahir bayinya kemudian dijahit. Saya tidak berani dijahit)"

"Aku nang dukun, mbak. Aku wedi lahir nang Rumah Sakit dan wedi operasi. Nang dukun bayiku lahir yo lahir selamet"

"(Saya di dukun, mbak. Saya takut lahir di Rumah Sakit dan takut operasi. Di dukun bayi saya lahir ya lahir dengan selamat)"

(In A 3)

Namun informan pendamping memberikan keterangan yang kontradiktif, seperti kutipan hasil wawancara berikut:

"Sebenarnya mereka tahu. Setiap kali periksa hamil ya sudah disampaikan. Namun mereka ya tetap memilih dukun sebagai penolong persalinan"

(In P 1)

Pengetahuan adalah informasi seseorang yang memiliki spesifikasi di bidang tertentu ${ }^{13}$. Diperlukan cara lain sehingga pengetahuan informan utama tentang persalinan yang sehat dan aman bisa dilakukan. Hal ini juga sejalan dengan hasil penelitian yang dilakukan Amelia donsu, faktor pengetahuan berhubungan signifikan terhadap pemilihan penolong persalinan $^{14}$.

Pengetahuan dan alih tehnologi membutuhkan waktu sebelum pengetahuan dan tehnologi tersebut benar - benar jadi milik masyarakat yang bersangkutan. Ada tiga faktor penghalang dalam pelaksanaan atau penerapan program yang disebut the three delays yaitu 1) rintangan budaya (cultural barrier), 2) rintangan sosial (social barrier), dan 3) rintangan psikologis (psychological barrier) ${ }^{10}$. Ketiganya perlu dicermati sehingga pengetahuan yang disampaikan menjadi milik masyarakat setempat.

Faktor Kepercayaan
Kepercayaan masyarakat terhadap penggunaan dukun sebagai penolong persalinan merupakan hal yang berpengaruh terhadap pembangunan derajat kesehatan ibu anak di Kota Surabaya. Hal ini seperti kutipan hasil wawancara berikut:

"Karo morotuoku dicelokno dukun seng biasane nulung aku ngelairno"

"(Oleh mertua saya dipanggilkan dukun yang biasanya menolong saya melahirkan)"

Hal ini sama seperti yang disampaikan oleh informan pendamping, kepercayaan masyarakat sangat berpengaruh pada pemilihan dukun sebagai penolong persalinan. Masyarakat menganggap dukun bisa membantu pertolongan persalinannya yang risiko tinggi. Hal ini seperti kutipan hasil wawancara dibawah ini:

"Pasien yang tak rujuk ke RSUD dan lahir di dukun dengan bangganya cerito di Posyandu, aku lair nang dukun, bu bidan. Iki bayiku yo sehat"

"(Pasien yang dirujuk ke RSUD dan lahir di dukun dengan bangganya cerita di Posyandu, saya lahir di dukun, bu bidan. Ini bayi saya ya sehat)"

(In P 2)

Hasil penelitian ini sama dengan hasil penelitian Aziato, Lydia bahwa sosio kultural berpengaruh terhadap pemilihan dukun sebagai penolong persalinan ${ }^{15}$.

\section{Faktor Akses Pelayanan Kesehatan}

Aksesibilitas pelayanan kesehatan adalah kemampuan setiap orang dalam mencari pelayanan kesehatan sesuai dengan yang mereka dibutuhkan. Dimensi akses meliputi secara fisik (termasuk masalah geografis), biaya, maupun akses secara sosial ${ }^{16}$.

Pemerintah Kota Surabaya telah berupaya dalam rangka meningkatkan 
akses pelayanan kesehatan bagi seluruh masyarakat. Pemerintah telah mendekatkan fasilitas kesehatan. seperti kutipan hasil wawancara berikut:

"Praktek Mandiri Bidan yo akeh dan dekat - dekat. Tapi sayangnya, bidan kelurahan kita tidak tinggal di Kelurahan"

"(Praktek Mandiri Bidan ya banyak dan dekat - dekat. Tapi sayangnya, bidan kelurahan kita tidak tinggal di Kelurahan)"

(In P 2)

Selain akses terhadap fasilitas kesehatan, pemerintah juga mendekatkan akses pembiayaan kesehatan. Secara finansial, komitmen pemerintah Indonesia diwujudkan dengan pemberian Jaminan Kesehatan Masyarakat (Jamkesmas) yang bertujuan untuk memberikan pelayanan kesehatan gratis termasuk pelayanan antenatal care, persalinan dan postnatal care bagi ibu dan bayi ${ }^{17}$. Seperti kutipan hasil wawancara dibawah ini:

"Semua ibu hamil yang tidak mampu sudah tak urusno SKM (Surat Keterangan Miskin) dan PBI (Penerima Bantuan Iuran), mbak"

(In P 1)

\section{Dari hasil wawancara dengan} informan utama, didapatkan hasil faktor biaya tidak menjadi penghambat keinginan ibu hamil untuk melahirkan di dukun. Faktanya dengan biaya yang tidak murah yaitu antara Rp 800.000,- sampai dengan Rp 1.000.000,- ibu hamil tetap memilih dukun sebagai penolong persalinan. Hal ini seperti kutipan hasil wawancara dibawah ini:

"Nang dukune aku mbayar wolungatus ewu rupiah" "(Di dukun, saya bayar delapan ratus ribu rupiah)"

"Mbayar satu juta, mbak. Itu lahiran tok. Nek pijet yo mbayar maneh"

“(Bayar satu juta, mbak. Itu melahirkan saja. Kalau pijat ya bayar lagi)"
(In A 3)

Hasil penelitian ini berbeda dengan penelitian yang dilakukan oleh Ridha, M. S.S.,dkk, faktor biaya berpengaruh pada pemilihan dukun sebagai penolong persalinan. Karena sesuai dengan pendapatan ibu sehari - harinya ${ }^{18}$.

\section{Faktor Keluarga}

Peran keluarga, mertua atau nenek masih berpengaruh pada pemilihan dukun sebagai penolong persalinan. Hal ini sesuai dengan kutipan hasil wawancara dibawah ini:

"Aku gak eroh nek arep ngelairno. Mertuoku nyeluk dukun"

"(Saya tidak tahu kalau akan melahirkan. Mertua saya memanggil dukun)"

"Ibukku yang manggil dukun ke rumah, mbak"

"(Ibu saya yang memanggil dukun ke rumah, mbak)"

(In A 2)

Hasil penelitian ini sama dengan hasil penelitian dilakukan Amelia donsu, dukungan suami berhubungan signifikan terhadap pemilihan penolong persalinan (Donsu, Amelia. 2014). Bagi masyarakat, lancar tidaknya persalinan ditentukan oleh perbuatan suami dan istrinya ${ }^{19}$. Dalam struktur masyarakat Indonesia masih menganut paham paternalistik, peran suami sebagai kepala rumah tangga sangat dominan dan akan menentukan dalam pemilihan penolong persalinan ${ }^{20}$.

\section{KESIMPULAN}

Dari penelitian yang telah dilakukan tentang pemilihan dukun sebagai penolong persalinan di wilayah kerja Puskesmas Bulak Banteng, Surabaya, ditinjau dari faktor pengetahuan, pengetahuan 
masyarakat tentang persalinan sehat dan aman masih kurang. Ditinjau dari faktor kepercayaan, faktor ini memegang peranan penting pada pemilihan dukun sebagai penolong persalinan. Ditinjau dari faktor akses pelayanan kesehatan, masyarakat di wilayah Puskesmas Bulak Banteng dengan mudah mengakses pelayanan kesehatan dan tidak ada kesulitan untuk pembiayaan kesehatan. Bahkan biaya persalinan di dukun lebih mahal. Namun ada permasalahan yaitu bidan kelurahan tidak berdomisili di Kelurahannya. Ditinjau dari faktor keluarga, keluarga memegang keputusan pada pemilihan dukun sebagai penolong persalinan.

Dari hasil penelitian diatas penulis menyarankan kepada Dinas Kesehatan Kota Surabaya memberikan kebijakan untuk bidan kelurahan berdomisili di Kelurahan sehingga masyarakat lebih mudah dipantau. Puskesmas bersama dengan lintas sektor menggiatkan kembali kemitraan bidan dukun di wilayahnya.

\section{UCAPAN TERIMA KASIH}

Dalam penelitian ini, peneliti mengucapkan terima kasih kepada:

1. Kepala Dinas Kesehatan Kota Surabaya;

2. Ketua Program Studi Pengembangan Sumber Daya Manusia, Sekolah Pascasarjana Universitas Airlangga Surabaya;

3. Kepala Puskesmas Bulak Banteng Surabaya; dan

4. Informan - informan.

\section{DAFTAR PUSTAKA}

1. Dinas Kesehatan Kota Surabaya. Profil Kesehatan Kota Surabaya. 2017.

2. Kementerian Kesehatan Republik Indonesia, Direktorat Jenderal Kesehatan Masyarakat. Modul
Pelatihan

Penanganan

Kegawatdaruratan Maternal dan Neonatal Bagi Dokter Umum, Bidan dan Perawat. 2018.

3. Kementerian Kesehatan Republik Indonesia. Pedoman Pelaksanaan Kemitraan Bidan dan Dukun. 2008.

4. Prawirohardjo, S. Paraji: Tinjauan Antropologi Kesehatan Reproduksi Dalam: Sarwono P., Editor. Bunga Rampai Obstetri dan Ginekologi Sosial. Jakarta: Yayasan Bian Pustaka Sarwono Prawirohardjo. 2005.

5. Anggorodi, R., Savitri M. Studi Kemitraan Bidan Dukun di Kabupaten Kediri, Jawa Tengah dan Kabupaten Cirebon, Jawa Barat. Laporan AKhir. Jakarta: Kerjasama FKM UI dengan MNH. 2004.

6. Hull VJ. Women, doctors, and family health care: Some Lessons From Rural Java. Studies in Family Planning. 1979;(10):313-325.

7. De Fretes, E., dkk. Analisis Pelaksanaan Program Kemitraan Bidan dan Dukun Ditinjau dari Aspek Input, Proses dan Output di Wilayah Dinas Kesehatan Kabupaten Fakfak Provinsi Papua Barat. JMKI. Desember 2016;(04):03.

8. Miller, Tina, and Smith, Helen. Establishing partnership with traditional birth attendants for improved maternal and newborn health: a review of factors influencing implementation. BMC Pregnancy and Childbirth. 2017;(17):365.

9. Anggorodi, R. Dukun Bayi dalam Persalinan oleh Masyarakat Indonesia. Makara, Kesehatan. Juni 2009 : (13):1.

10. Dressler WW. Medical Anthropology: Toward a Third Moment in Social 
Science? Medical Anthropology Quarterly. 2001;(15):455-465.

11. Frankenberg, E., dkk. Contrceptive Use in A Changing Service Environment: Evidence From Indonesia During The Economic Crisis. Studies in Family Planning. 2003;(34):103-116.

12. Notoatmodjo, Soekidjo. Ilmu Perilaku Kesehatan. Jakarta: Rineka Cipta. 2014.

13. Spencer,Lyle, M. Jr. and Signe M. Spencer. Competency at Work : Models for Superior Performance. New York : John Wiley \& Sons, Inc. 1993.

14. Donsu, Amelia. Faktor - faktor yang berhubungan dengan pemanfaatan penolong persalinan di Desa Moyongkota Baru Kecamatan Modayag Barat. JIB. Januari - Juni 2014;(2):1.

15. Aziato, Lydia and Cephas N. Omenyo. Initiation of traditional birth attendants and their traditional dan spiritual pratices during pregnancy dan childbirth. BMC Pregnancy and Childbirth.

https://doi.org/10.1186/s12884-0181691-7. 2018.

16. Dwi, L. A., dkk. Aksesibilitas Pelayanan Kesehatan di Indonesia. Yogyakarta: PT. Kanisius. 2016.

17. Hermawan, Asep. Gambaran Pilihan Persalinan oleh Tenaga Kesehatan Non Kesehatan/ Tanpa Pertolongan di Indonesia. Jurnal Kesehatan Reproduksi. 22 Juni 2017;(08):01.

18. Ridha, M.S.S., dkk. Analisis Pemanfaatan Pertolongan Non Tenaga Kesehatan di Kabupaten Kolaka Timur. JMKI. April 2017; (5):1.

19. Yusnita, Ira, dkk. Analisis Rendahnya Pemanfaatan Layanan Persalinan Tenaga Kesehatan di Wilayah Kerja Puskesmas Wakaokili Kabupaten Buton. JMKI. April 2015;(03):01.

20. Astuti, P.A, dkk. Analisis Alasan Pemilihan Penolong Persalinan oleh Ibu Bersalin di Kabupaten Semarang. JMKI. Desember 2014;(02):03. 